\title{
Effect of Medium pH and Light on Quinidine Production in Cinchona calisaya Wedd. Endophytic Fungi
}

\section{Cinchona calisaya Wedd. Endofit Mantarında Kinidin Üretiminde Ortamın pH'sının ve Işığın Etkisi}

\author{
(D) Indriana RAHMAWATI1, (D) Gayuh RAHAYU1*, (D) Diah RATNADEWI1, (D) Suminar ACHMADI2 \\ ${ }^{1}$ Bogor Agricultural University Faculty of Mathematics and Natural Sciences, Department of Biology, Bogor, Indonesia \\ 2Bogor Agricultural University Faculty of Mathematics and Natural Sciences, Department of Chemistry, Bogor, Indonesia
}

\begin{abstract}
Objectives: Quinidine has pharmaceutical importance as an antimalarial, antiarrhythmia, antimicrobial, anticancer, antioxidant, astringent, and bitter flavoring agent. Quinidine is in high demand, yet its production from the bark of the quina tree (Cinchona calisaya) is limited. Quinidine production from quina tree fungal endophytes, namely Aspergillus sydowii, Diaporthe sp., Diaporthe lithicola, Fusarium oxysporum, and F. solani is lower than the quinidine content of the tree bark. This study attempted to increase quinidine production from these fungi. This research aimed to determine the optimum culture conditions for quinidine production from endophytic fungi.

Materials and Methods: Quinidine was produced by in vitro culturing of the fungal endophytes in potato dextrose broth (PDB) medium under different culture conditions, i.e., a combination of an initial medium $\mathrm{pH}$ of 6.2 or 6.8 , with or without light, in a static condition for 21 days of incubation at room temperature. Production under natural daylight in PDB medium without $\mathrm{pH}$ modification was used as the control. At the end of the incubation period, the mycelial mass was separated from the filtrate. The dried biomass and chloroform-extracted filtrate were weighed. Quinidine in the extract was analyzed qualitatively and quantitatively using high-performance liquid chromatograph.

Results: Quinidine production was affected by both light and the initial $\mathrm{pH}$ of the medium, depending on the fungal strain used. A significant increment in quinidine production, approximately 1.1-9.3-fold relative to its respective control was obtained from all fungi under their optimum conditions. Quinidine production in most of the fungi was significantly correlated with their biomass production but not with their extract production. Of those five fungi, F. solani that was cultured in PDB medium with an initial pH of 6.2 and incubated under continuous light produced the highest concentration of quinidine with low biomass.

Conclusion: The quinidine production of all fungal endophytes studied was affected by the culture conditions. F. solani is the most promising fungus for use as a quinidine production agent.
\end{abstract}

Key words: Fungal endophytes, in vitro culture, optimization, light, $\mathrm{pH}$, quinidine

ÖZ

Amaç: Kinidin, antimalaryal, antiaritmik, antimikrobiyal, antikanser, antioksidan, astrinjen ve acı tatlandırıcı olarak kullanıldığı için farmasötik öneme sahiptir. Kinidin yoğun talep görmesine rağmen, kinidin kaynağı olan quina ağacı (Cinchona calisaya) kabuğundan üretimi sınırlıdır. Quina ağacı fungal endofitleri olan Aspergillus sydowii, Diaporthe sp., Diaporthe lithicola, Fusarium oxysporum ve F. solani'den kinidin üretimi, ağaç kabuğundaki kinidin içeriğinden daha düşüktür. Bu çalışmada endofitik mantarların kinidin üretiminin belirlenmesi optimum kültür koşullarının belirlenmesi amaçlanmıştır.

Gereç ve Yöntemler: Kinidin farklı kültür koșullarında patates dekstroz et suyu (PDB) ortamında fungal endofitlerin in vitro kültürlenmesi yoluyla üretilmiş, başlangıç ortamı olarak pH 6,2 veya 6,8' in kombinasyonları ışıklı/ışıksız olarak kullanılarak statik koşullarda oda sıcaklığında 21 gün süreyle inkübasyona tabi tutularak üretilmiștir. pH'yi değiștirmeden PDB ortamında doğal gün ışığı altında üretim kontrol olarak kullanılmıștır. İnkübasyon süresinin sonunda, misel kütlesi filtrattan ayrılmıştır. Kurutulmuș biyokütle ve kloroform ile ekstre edilmiş filtrat tartılmıştır. Ekstredeki kinidin, kalitatif ve kantitif olarak yüksek basınçlı sıvı kromatografisi kullanılarak analiz edilmiștir. 
Bulgular: Kinidin üretimi, mantar suşuna bağlı olarak ortamın hem ışık hem de ilk pH'sinden etkilenmiştir. Optimum koşullar altında ilgili kontrolüne göre tüm mantarların kinidin üretiminde yaklașık 1,1-9,3 kat belirgin bir artıș elde edilmiștir. Mantarların çoğunda kinidin üretimi, ekstrakt üretimi ile değil, biyokütle üretimi ile anlamlı ölçüde korele bulunmuştur. Bu beş mantardan, ilk pH'si 6,2 olarak ve sürekli ışık inkübasyonu altında PDB ortamında kültürlenen $F$. solani, düşük biyokütle ile en yüksek kinidin konsantrasyonunu üretmiştir.

Sonuç: Çalışılan tüm mantar endofitlerinin kinidin üretimi, kültür koșullarından etkilenmiștir. F. solani, kinidin üretim ajanı olarak kullanılacak en umut veren mantardır.

Anahtar kelimeler: Fungal endofitler, in vitro kültür, optimizasyon, ışık, pH, kinidin

\section{INTRODUCTION}

Quinoline is a major secondary metabolite produced in the bark and root of the quina tree (Cinchona, Rubiaceae). There are four members of quinoline, i.e., quinine, quinidine, cinchonine, and cinchonidine. These substances are commonly used as antimalarial drugs. Malaria is a very dangerous disease and a leading cause of death worldwide. Malaria is caused by four species of Plasmodium. The most serious form of malaria is caused by Plasmodium falciparum and $P$. vivax. The goal of the World Health Organization in 2016-2030 is to either reduce the incidence of malaria by at least $90 \%$ or eradicate the disease in all countries of the world. ${ }^{2}$

Quinidine is actually three-fold more effective at treating malaria caused by $P$. falciparum than the other compounds mentioned. Further, it has the widest range of uses out of all members of the quinoline family. In addition to its application as an antimalarial drug, quinidine is also useful as an antimicrobial, ${ }^{3}$ anticancer, ${ }^{4}$ antioxidant, ${ }^{5}$ astringent, bitter flavoring, ${ }^{6}$ and antiarrhythmia agent. $^{7}$ As an antimalarial drug, quindine binds to free heme to prevent hemozoin formation. The production of hemazoin is a heme detoxification system in the malaria parasite. ${ }^{8}$ Free heme is very toxic to the parasite, as it can induce oxidative stress, which leads to the parasite's death. As an antibacterial, quinidine inhibits the internalization or invasion of bacteria. ${ }^{9}$ As an anticancer agent, quinidine can arrest MCF-7 human breast cancer cells in the G1 phase of the cell cycle and lead to apoptotic cell death. ${ }^{10}$ As an antiarrhythmic drug, quinidine is classified as class la sodium channel blocker."1 Quinidine is very effective at treating atrial fibrillation and short QT syndrome. It can also be used as an anticonvulsant, an anticholinergic drug, and an antagonist of $\alpha$-adrenergic and muscarinic drugs. ${ }^{12}$ Therefore, increased quinidine production is needed to fill the growing pharmaceutical demand.

Currently, quinidine availability is solely dependent on the bark and root of the quina tree. Indonesia has shown a drastic decline in the quina tree population and a consequent decline in quinidine production. Efforts have been made to increase the plant population and quinidine production, i.e., quina tree replanting, tree selection through hybridization and clonal propagation $n^{7,13}$ and quinidine production through cell culture..$^{14}$ However, the quinidine supply is still limited. Therefore, it is necessary to explore other natural resources for quinidine production.

Endophytic fungi can produce secondary metabolites similar to those of their host plant. ${ }^{15}$ Endophytic fungi isolated from the Cinchona tree are potential sources of quinidine production. ${ }^{16-21}$
Some of Cinchona calisaya Wedd. endophytic fungi, i.e., Aspergillus, Diaporthe, and Fusarium species were reported to produce quinidine as well as other quinolines. ${ }^{21}$ Diaporthe sp. CLF-J, a fungal endophyte of C. ledgeriana (Howard) Bern. Moens ex Trimen, was reported to produce low levels of quinidine, i.e., $\left\langle 10 \mu \mathrm{g} / \mathrm{L} .^{18}\right.$ Therefore, quinidine production should be determined and improved simultaneously by optimizing fungal culture conditions.

The factors affecting secondary metabolite production in fungi are the initial $\mathrm{pH}$ of the culture medium ${ }^{18,22,23}$ and light intensity. ${ }^{24-26}$ The effect of these factors varies from induction to inhibition of secondary metabolite production, depending on the fungal strain used. Presumably, these abiotic factors may induce quinidine production in some Cinchona endophytic fungi but not in others. Therefore, the effects of medium $\mathrm{pH}$ and light intensity on quinidine production and biomass in five different strains of $C$. calisaya endophytic fungi in submerged fermentation were investigated.

\section{MATERIALS AND METHODS}

\section{Fungal culture preparation}

The fungal strains used in this study (Aspergillus sydowii Institut Pertanian Bogor Culture Collection (IPBCC) 15.1258, Diaporthe sp. IPBCC 15.1292, D. lithicola IPBCC 15. 1314, Fusarium oxysporum IPBCC 15.1250, and F. solani IPBCC 15.1247) were isolated in 2012 from healthy leaf, fruit, twig, bark, and petiole of $C$. calisaya, respectively. The trees were grown in the Tea and Quina Research Centre Orchard in Gambung, West Java, Indonesia. ${ }^{21}$ The fungal cultures were maintained at $-80^{\circ} \mathrm{C}$ in glycerol trehalose and maintained in the Bogor Agricultural University Culture Collection Indonesia for 3 years. The stock cultures were rejuvenated on potato dextrose agar (PDA) and incubated at $25^{\circ} \mathrm{C}$. A 7 day-old culture was used as a working culture (Figure 1).

\section{Optimization of culture conditions for quinidine production}

Each fungus was cultivated individually in liquid fermentation medium. Three pieces of mycelial plugs $(0.8 \mathrm{~cm}$ dia) were taken from the edge of the PDA culture of each fungal colony then transferred into $200 \mathrm{~mL}$ potato dextrose broth (PDB), in $250 \mathrm{~mL}$ Erlenmeyer flasks. The $\mathrm{pH}$ of the PDB was adjusted to either 6.2 or 6.8 prior to sterilization by adding phosphate buffer. The culture conditions for quinidine production by these fungi were the combination of the initial $\mathrm{pH}$ of the medium $(6.2$ and 6.8) either with continuous white light (about 1700 lux) or without light (dark). Production under natural light (daylight) in PDB medium without $\mathrm{pH}$ modification $(5.1 \pm 0.2)$ was used as a 
control. Three replicates were performed for each treatment The cultures were then incubated for 21 days under static conditions. At the end of the incubation period, quinidine was extracted, weighed, and analyzed. In addition, the final $\mathrm{pH}$ value of the medium was measured, and the dry biomass and dry extract were weighed.

\section{Quinidine extraction and analysis}

The mycelial mass was separated from the filtrate using filter paper and dried in an oven at $60^{\circ} \mathrm{C}$ for 24 hours or until a constant dry mass was reached. The biomass dry weight represented biomass production. The filtrate was extracted by adding chloroform $\left(\mathrm{CHCl}_{3}, \geq 99.8 \%\right)$ at a 1:1 ratio. The mixture was homogenized and allowed to stand for 24 hours. The mixture was transferred to a separatory funnel and allowed to stand for a few seconds to form two layers. Afterward, the bottom layer was removed and evaporated using a rotary evaporator at $45^{\circ} \mathrm{C}$ and 60 rpm until a pellet was formed. ${ }^{21}$ The pellet was weighed and designated as the extract. Finally, the extract was stored at $4^{\circ} \mathrm{C}$ as the stock material for quinidine analysis.

Quinidine was analyzed using a Shimadzu Prominence 20AD high-performance liquid chromatograph (HPLC). The extract was first dissolved in $1 \mathrm{~mL}$ chloroform. About $20 \mu \mathrm{L}$ of that solution was injected into the HPLC. The analytical conditions was set as follows: Thermo C-18 column $(4.6 \times 250 \mathrm{~mm})$, methanol:acetonitrile $(80: 20)$ as the mobile phase, $1.0 \mathrm{~mL} \mathrm{sec}{ }^{-1}$ flow rate, $40^{\circ} \mathrm{C}$ column temperature, and a detection wavelength of $210 \mathrm{~nm} .^{27}$ The presence of quinidine was determined on the basis of the peak that appeared at the same retention time $(\mathrm{Rt})$ as the quinidine standard. The concentration of quinidine was determined using a formula representing the correlation between 2, 4, 8, 10, and $12 \mathrm{ppm}$ standard quinidine with their area under the corresponding peak. The formula is $y=m x+b$, where $y$ is the area under the standard quinidine peak, $m$ is the regression coefficient, $x$ is the quinidine concentration, and $b$ is a constant.

\section{Experimental design}

A factorial design with a combination of two factors, i.e., light exposure (with or without light) and the initial $\mathrm{pH}$ of the medium $(\mathrm{pH} 6.2$ and 6.8) was used in this research. The production condition in PDB medium without $\mathrm{pH}$ modification incubated at room temperature was used as a control. The treatments were tested on five $C$. calisaya endophytic fungi, i.e., A. sydowii,
Diaporthe sp., D. lithicola, F. oxysporum, and F. solani. Each treatment was applied in triplicate to produce a total of 75 experimental units.

\section{Statistical analysis}

Data were analyzed statistically using analysis of variance followed by Duncan's multiple range test (DMRT), both at the $5 \%$ level of significance. Correlation of quinidine production with biomass dry weight and with extract weight were calculated using Pearson's correlation coefficient $\left(r_{p}\right)$. The correlation was categorized into five groups, i.e., weakest (0.00-0.19), weak (0.20-0.39), moderate (0.40-0.69), strong (0.70-0.90), and strongest $(0.90-1.00){ }^{28}$

\section{RESULTS}

\section{Quinidine production}

The HPLC chromatogram of all fungal extracts showed two peaks, indicating the presence of quinidine and an unknown substance (Figure 2A-E). Quinidine was detected to have an Rt similar to that of the quinidine standard (Rt 9.9412 \pm 1.9 minutes, Figure $2 \mathrm{~F}$ ), and the unknown compound had a peak at \pm Rt 5 minutes (Figure 2A-E). The quinidine standard concentration was highly correlated $\left(R^{2}: 1\right)$ with its area under the respective peak; therefore, the regression equation $y=123.915 x+1442.8$ was further used to calculate the quinidine concentration in the extract.

The amount of quinidine varied depending on the fungal strain used and the incubation conditions. A. sydowii, F. oxysporum, and $F$. solani produced the maximum concentration of quinidine under continuous light incubation with an initial medium $\mathrm{pH}$ of 6.2. In contrast, the maximum quinidine production of Diaporthe sp. and $D$. lithicola were obtained under dark incubation with an initial medium $\mathrm{pH}$ of 6.8. Under optimum conditions, all fungi (A. sydowii, Diaporthe sp., D. lithicola, F. oxysporum, and $F$. solani) produced quinidine at their highest concentrations, i.e., 29.026 (Figure 3A), 8.913 (Figure 3B), 11.148 (Figure 3C), 23.967 (Figure 3D), and $65.177 \mu \mathrm{g}$ (Figure 3E), respectively, in $200 \mathrm{~mL}$ PDB medium after 21 days of incubation.

The quinidine production of all fungi increased significantly ( $p<0.05$ ) under optimum conditions. A. sydowii (Figure 3A), Diaporthe sp. (Figure 3B), D. lithicola (Figure 3C), F. oxysporum (Figure 3D), and F. solani (Figure 3E) increased

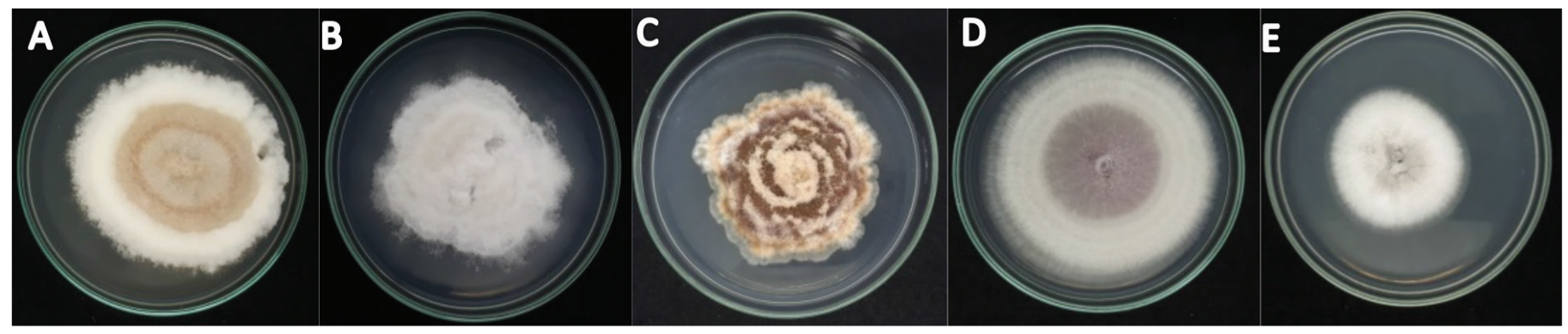

Figure 1. (A) Aspergillus sydowii IPBCC 15.1258, (B) Diaporthe sp. IPBCC 15.1292, (C) Diaporthe lithicola IPBCC 15. 1314, (D) Fusarium oxysporum IPBCC 15.1250, (E) F. solani IPBCC 15.1247

IPBCC: Institut Pertanian Bogor Culture Collection 

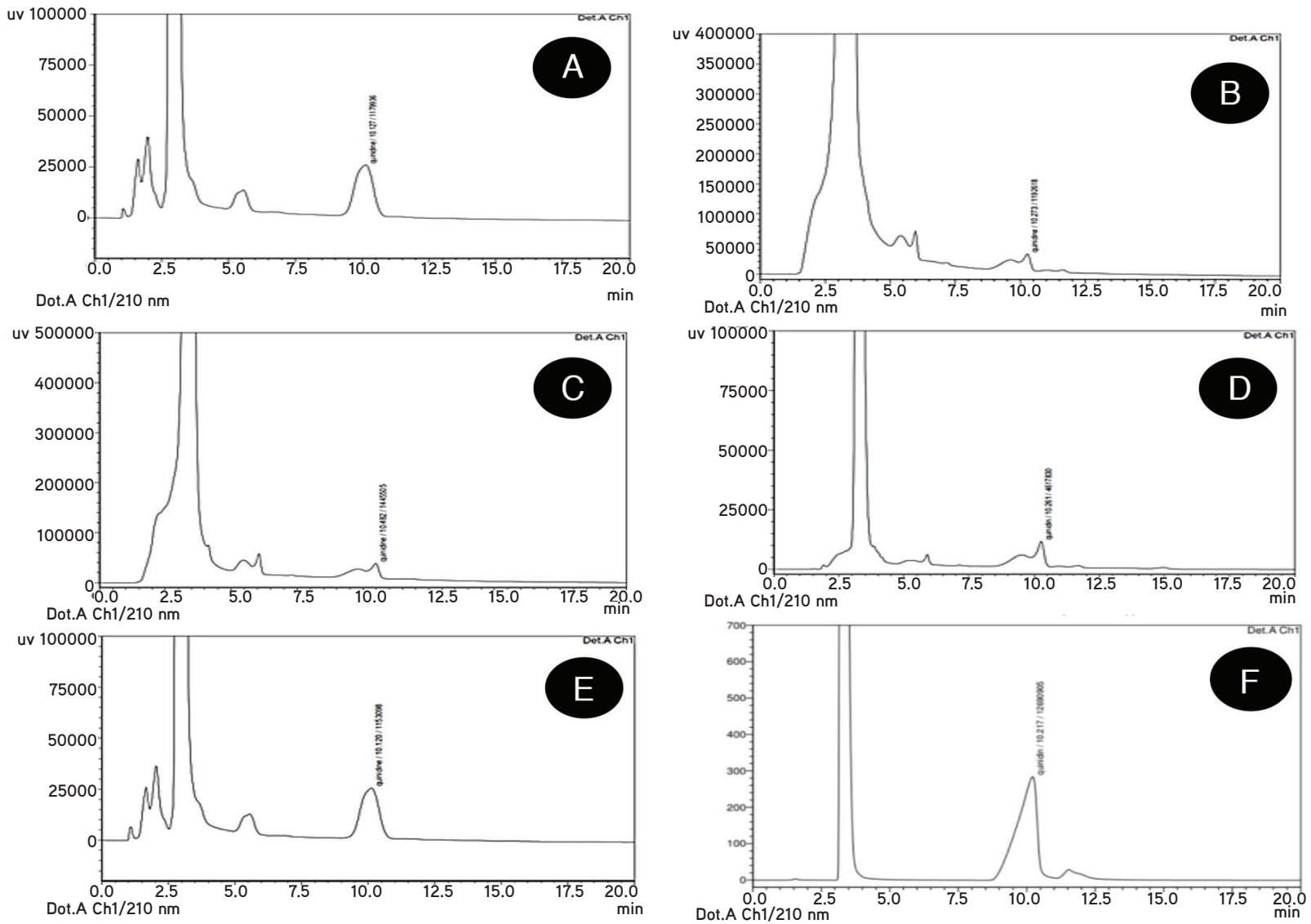

Figure 2. High-performace liquid chromatogram of (A) Aspergillus sydowii, (B) Diaporthe sp., (C) Diaporthe lithicola, (D) Fusarium oxysporum, (E) F. solani, and $(F)$ quinidine standard

2.7-, 1.6-, 1.1-, 9.3-, and 6.0-fold, respectively, compared with their corresponding controls. The DMRT test ( $p<0.05)$ indicated that quinidine production in $F$. solani and Diaporthe sp. increased significantly under the combined conditions of light and initial medium $\mathrm{pH}$, whereas the other strains were affected only by either light or the initial $\mathrm{pH}$ of the medium. Quinidine production in $F$. solani increased significantly with continuous light and an initial medium $\mathrm{pH}$ of 6.2, whereas that of Diaporthe sp. increased with dark incubation and an initial medium pH of 6.8. Unlike F. solani and Diaporthe sp., quinidine production in $F$. oxysporum increased under continuous light regardless of the $\mathrm{pH}$, and that of $A$. sydowii and $D$. lithicola was only affected by the initial $\mathrm{pH}$ of the medium.

Biomass and extract production and the final $\mathrm{pH}$ of the culture medium

The optimum condition for biomass production of each fungus varied and was different from those for quinidine production except for that of $F$. oxysporum. This fungus produced both the maximum quinidine concentration and biomass dry weight $(0.247 \mathrm{~g})$ under continuous light and an initial medium $\mathrm{pH}$ of 6.2 (Figure 4A). Like F. oxysporum, A. sydowii grew better $(0.387$ g) under continuous light but at a different initial medium $\mathrm{pH}$ ( $\mathrm{pH}$ 6.8) (Figure 4B). In contrast, that of D. lithicola (0.307 g) occurred under the dark condition with an initial medium $\mathrm{pH}$ of 6.2 (Figure $4 \mathrm{C}$ ). The highest biomass production of all fungi occurred in modified-pH medium, and the highest biomass production of Diaporthe sp. (Figure 4D) and F. solani (Figure 4E) were obtained under the control conditions, i.e., $0.351 \mathrm{~g}$ and $0.470 \mathrm{~g}$, respectively.

The optimum conditions for extract (pellet) production were also different from those for quinidine production, except in Diaporthe sp. and D. lithicola. Similar to their quinidine production, Diaporthe sp. (Figure 5A) and D. lithicola (Figure 5B) produced the highest extract dry weight, i.e., $0.765 \mathrm{~g}$ and $0.115 \mathrm{~g}$, respectively, under darkness and at an initial medium $\mathrm{pH}$ of 6.8. Under these conditions, $F$. solani (Figure $5 C$ ) also produced the highest extract dry weight $(0.102 \mathrm{~g})$, whereas that of $A$. sydowii (Figure 5D) and F. oxysporum (Figure 5E) were obtained under control conditions, i.e., $0.164 \mathrm{~g}$ and $0.122 \mathrm{~g}$, respectively. The extract production of each fungus did not reflect the quinidine production. Of the fungi studied, Diaporthe sp. produced the highest extract dry weight, but its quinidine production was the lowest (Table 1). Based on extract production, the quinidine content in the extract of $F$. solani was the highest $(1551.83 \mu \mathrm{g} / \mathrm{g}$ extract), followed by that of $A$. sydowii, F. oxysporum, D. lithicola, and Diaporthe sp., i.e., 518.32, 230.45, 96.94, and $11.65 \mu \mathrm{g} / \mathrm{g}$ extract, respectively. 
Correlation of quinidine with biomass and extract production Quinidine production can be either negatively or positively correlated with the corresponding biomass production (Table 2). The correlation can also either be significant or insignificant ( $p<0.1$ ). Of the fungi studied, only $F$. solani and $F$. oxysporum showed a significant correlation. In $F$. solani, quinidine production was strongly negatively $\left(r_{p}:-0.862\right)$ correlated with biomass production. In contrast, there was a strong postive correlation between quinidine and biomass production in $F$. oxysporum $\left(r_{p}\right.$ :
0.835). In addition, $D$. lithicola showed a negative correlation $\left(r_{p}\right.$ : -0.595 , moderate), albeit at a lower level of significance ( $p<0.2$ ). In contrast, quinidine production in $A$. sydowii and Diaporthe sp. was not correlated with biomass production. The correlation coefficients $\left(r_{p}\right)$ for the latter two fungi were 0.002 (weakest) and 0.199 (weak), respectively.

Quinidine and extract production also showed a similar pattern of correlation. However, most of the fungi (A. sydowii,

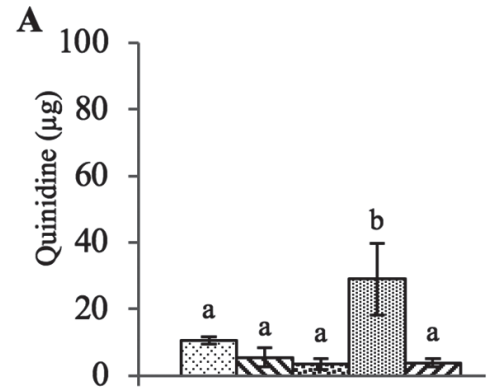

A. svdowii

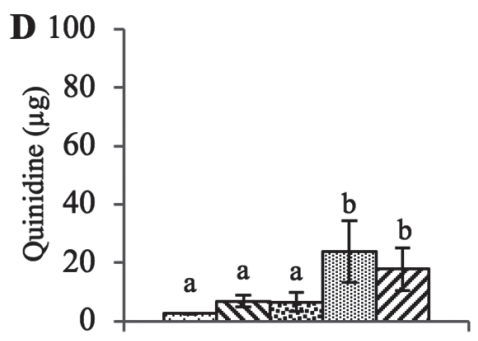

F. oxvsporum

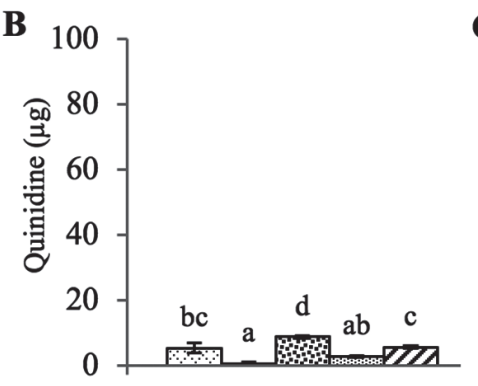

Diaporthe sp.

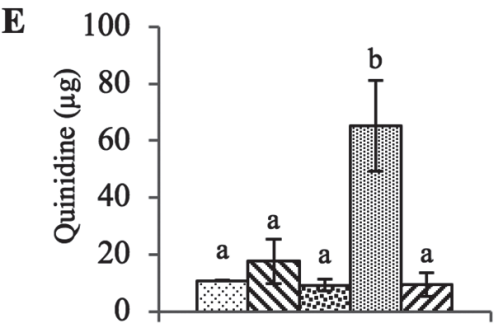

F. solani

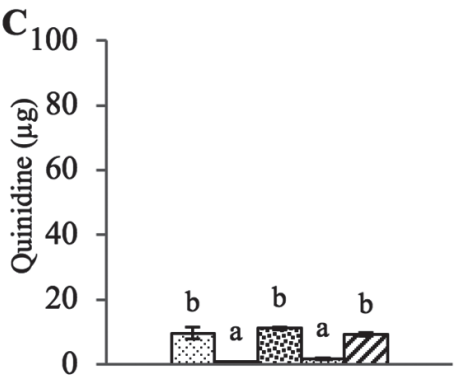

D. lithicola

Control

Dark- $\mathrm{pH} 6.2$

Dark- $\mathrm{pH} 6.8$

Light- $\mathrm{pH} 6.2$

DT Light- $\mathrm{pH} 6.8$

Figure 3. Quinidine production by Cinchona calisaya endophytic fungi in $200 \mathrm{~mL}$ potato dextrose broth. Bar data followed by the same letter not significantly different in Duncan's multiple range test at the $5 \%$ level of significance

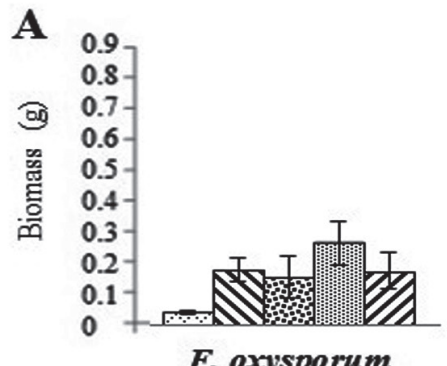

F. oxysporum

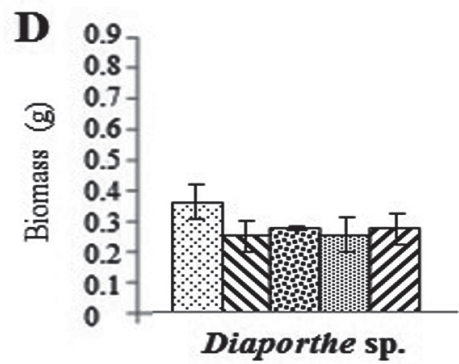

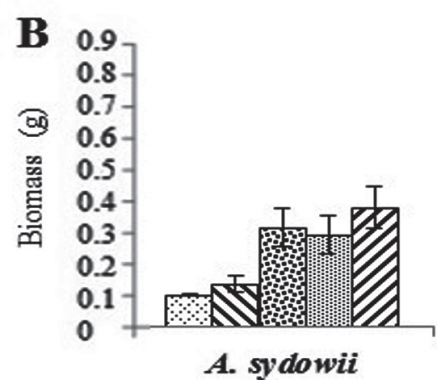

A. sydowii

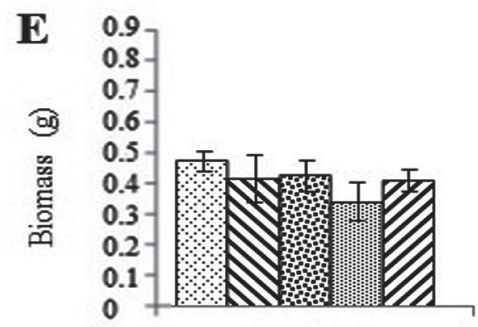

F. solani

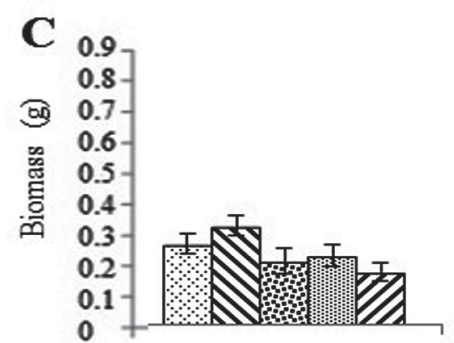

D. lithicola

Figure 4. Biomass production by Cinchona calisaya endophytic fungi in four treatments in $200 \mathrm{~mL}$ potato dextrose broth. A vertical bar above the data block indicates the standard error 


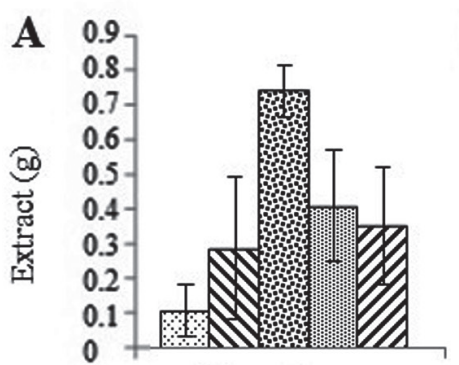

Diaporthe sp.

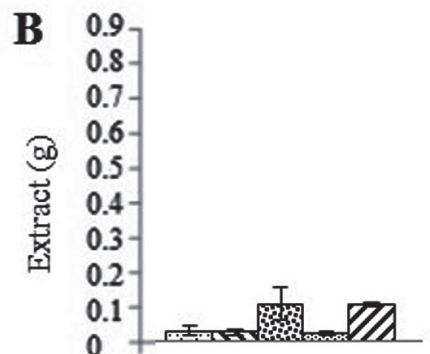

D. lithicola

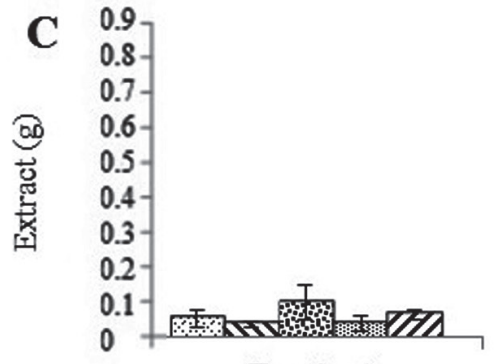

F. solani

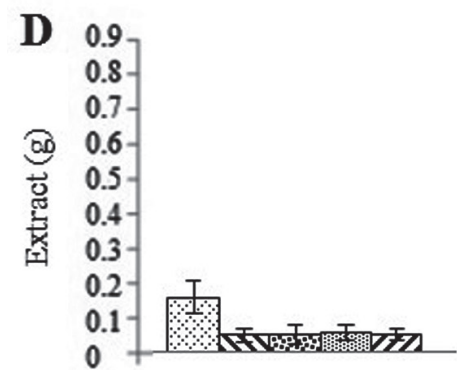

A. sydowii

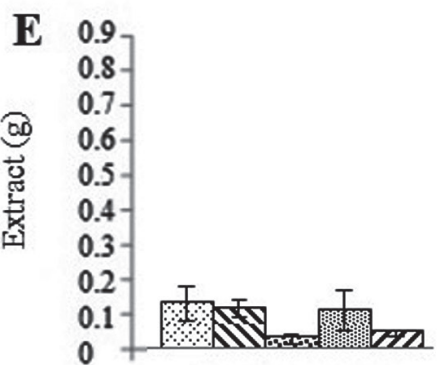

F. oxysporum

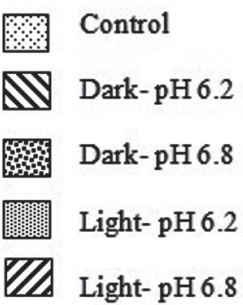

Figure 5. Extract production by Cinchona calisaya endophytic fungi in four treatments in $200 \mathrm{~mL}$ potato dextrose broth. Vertical line above the data block indicates the standard error

\section{Table 1. Quinidine content in alkaloid extract}

\begin{tabular}{lllll}
$\begin{array}{l}\text { Cinchona } \\
\text { calisaya } \\
\text { endophytic fungi }\end{array}$ & $\begin{array}{l}\text { Optimum } \\
\text { condition }\end{array}$ & $\begin{array}{l}\text { Quinidine } \\
(\mu \mathrm{g})^{*}\end{array}$ & $\begin{array}{l}\text { Extract } \\
(\mathrm{g})^{*}\end{array}$ & $\begin{array}{l}\text { Quinidine } \\
\text { extract } \\
(\mu \mathrm{g} / \mathrm{g})\end{array}$ \\
\hline $\begin{array}{l}\text { Fusarium solani } \\
\text { Fusarium } \\
\text { oxysporum }\end{array}$ & Light-pH 6.2 & 65.177 & 0.042 & 1551.83 \\
\hline $\begin{array}{l}\text { Aspergillus } \\
\text { sydowii }\end{array}$ & Light-pH 6.2 & 23.967 & 0.104 & 230.45 \\
\hline $\begin{array}{l}\text { Diaporthe sp. } \\
\text { Diaporthe lithicola }\end{array}$ & Dark-pH 6.8 & 8.913 & 0.764 & 11.65 \\
\hline
\end{tabular}

*: $200 \mathrm{~mL}$ production

Table 2. Correlation of quinidine production with biomass production and with extract production based on the Pearson's correlation test

\begin{tabular}{lll}
\multirow{2}{*}{$\begin{array}{l}\text { Cinchona calisaya endophytic } \\
\text { fungi }\end{array}$} & \multicolumn{2}{l}{$\begin{array}{l}\text { Coefficient correlation of } \\
\text { quinidine production with }\end{array}$} \\
\cline { 2 - 3 } & Biomass $\left(r_{p}\right)$ & Extract $\left(r_{p}\right)$ \\
\hline Fusarium solani & $-0.862^{*}$ & -0.493 \\
\hline Fusarium oxysporum & $0.835^{*}$ & -0.120 \\
\hline Aspergillus sydowii & 0.002 & 0.030 \\
\hline Diaporthe sp. & 0.199 & 0.559 \\
\hline Diaporthe lithicola & $-0.595^{* *}$ & $0.708^{* *}$ \\
\hline
\end{tabular}

$r_{p}$ : Pearson's correlation, *: Significant at $\alpha 0.1,{ }^{* *}$ : Significant at $\alpha 0.2$
Diaporthe sp., F. oxysporum, and F. solani) showed insignificant correlations, except in the case of $D$. lithicola, where the correlation was strongly positive and significant $\left(r_{p}: 708, p<0.2\right)$.

\section{DISCUSSION}

Only two of the fungal strains used in this study had ever been investigated for quinoline production. ${ }^{21}$ In that previous study, Diaporthe sp. and D. lithicola were grown under similar conditions to this study, and those fungi were reported to produce quinine. ${ }^{21}$ In contrast, quinine was not detected in the current study. Further, only quinidine was detected. All these quinolines (quinine, quinidine, cinchonine, and cinchonidine) are synthesized from the same structure; therefore, the possibility exists of structural changes among these compounds.,29,30 Quinidine ws the only quinoline compound produced in this study, as quinidine is probably structurally more stable than quinine.

The quinidine biosynthetic pathway in C. calisaya endophytic fungi has not yet been clarified. In Cinchona, the quinoline biosynthetic pathway is hypothetically synthesized from tryptophan and geraniol to form two intermediates, strictosidine and cinchonaminal, prior to the formation of cinchonidinone. ${ }^{7}$ Cinchonidinone becomes a basal substance for the synthesis of the four quina alkaloids. C-8 epimerization of cinchonidinone via enol will form cinchoninone. ${ }^{7}$ Both cinchonidinone and cinchoninone are catalyzed by nicotinamide adenine dinucleotide phosphate oxidoreductase to form cinchonidine and cinchonine, respectively. Moreover, cinchonidinone may form quininone by the hydroxylation and methylation, as do cinchoninone to form quinidinone. Quininone is reduced to quinine, while quinidinone is reduced to quinidine. Quinidine can also be synthesized 
from quinine by oxidation, epimerization, and reduction steps. Cinchonidine and quinine can be differentiated by their $\mathrm{R}$ groups, a hydrogen in cinchonidine, and a methoxy in quinine. Quinine is diastereoisomer of quinidine, as are cinchonine and cinchonidine.

In this study, the medium became more acidic at the end of the incubation period. This means that the $\mathrm{pH}$ of the medium was not buffered. It is expected that a medium with an uncontrolled $\mathrm{pH}$ will create conditions conducive to greater quinidine production. With a dynamic $\mathrm{pH}$ level that decreases from $\mathrm{pH} 6.5$ to $\mathrm{pH} 3.8$ during incubation, swainsonina alkaloid production was induced to a higher level than at a constant $\mathrm{pH}\left(\mathrm{pH}\right.$ 6.5). ${ }^{31}$ A preliminary study showed that no quinidine was detected in hyphal cells. The acidity of the medium might influence the permeability of the cell wall, thereby affecting nutrient uptake from the environment into cells. ${ }^{32}$ and simultaneously allows the quinidine produced in the cell to be excreted into the medium. This simplifies the harvesting of quinidine. In addition, the $\mathrm{pH}$ may also affect the expression of genes associated with the synthesis of secondary metabolites and enzyme activity. ${ }^{33}$

Not only $\mathrm{pH}$ but also light exposure affects quinidine production. This is in accordance with studies on other secondary metabolites. ${ }^{22,34-37}$ Secondary metabolite production of Penicillium isariiforme was inhibited by light, ${ }^{34}$ in contrast to that of $A$. flavus and A. ochraceus, which were induced by light. ${ }^{35} \mathrm{~F}$. verticilloides, Isaria farinosa, and Emericella nidulans produced maximum secondary metabolites with dark incubation and an initial synthetic medium $\mathrm{pH}$ of $5.6^{36} \mathrm{~F}$. graminearum produced a higher quantity of trichothecenes when it was grown under dark conditions rather than under light exposure. ${ }^{38}$ Fusarium spp. from Taxus wallichiana bark produced maximum secondary metabolites under optimum conditions, which were medium $\mathrm{pH} 6$ and daylight incubation, ${ }^{22}$ whereas $A$. terreus from seaweed Codium decorticatum produced maximum antibacterial compounds at an initial medium $\mathrm{pH}$ of 5.5 and with daylight incubation. ${ }^{23}$ In addition, blue light inhibited mycotoxin production in A. flavus, A. parasiticus, and Alternaria alternata. ${ }^{39}$ Green light stimulated citrinin production by Monascus ruber. ${ }^{37}$

Light is a crucial signal for every living cell. It seems that not only secondary metabolite production but also regulation of gene transcription, enzyme activation, nutrient uptake, reproduction, morphogenesis, cell wall components, and metabolism of lipids, nucleic acids, and amino acids involves metabolic pathways. ${ }^{25}$ Blue light stimulates sexual reproduction in Phycomyces blakesleeanus. ${ }^{40}$ Mycelia of Fujikuroi gibberella are orange and produce maximum carotenoids when incubated under light conditions, yet the mycelia become white and produce low amounts of carotenoids when incubated under dark conditions. ${ }^{41}$ Glucose absorption by $A$. ornatus decreased significantly when it was incubated under light conditions. In this case, light may stimulate biosynthesis of an inhibitor that blocks glucose absorption into fungal cells. ${ }^{42}$

In vitro growth of a microorganism is often correlated with its secondary metabolite production. ${ }^{43}$ The correlation can be either negative or positive, as shown in this study. When biomass production was negatively correlated with quinidine production, primary metabolism was more supported than secondary metabolism. Otherwise, primary metabolism is inhibited and shifted to secondary metabolism. When the correlation is positive, the carbon source might be used for both primary and secondary metabolism.

During in vitro production, endophytic fungi produced are not only beneficial secondary metabolites but may also produce toxins. F. oxysporum $f$. sp. lycopersici has been reported to produce fusaric acid after 3 days of incubation; maximum production was reached after 10 days of incubation in potato sucrose broth. ${ }^{44} \mathrm{~F}$. oxysporum could also produce fumonisin in glucose yeast asparagine malic acid medium at $25^{\circ} \mathrm{C}$ for a 2 -week incubation period. ${ }^{45}$ Fumonisin has high solubility in water, methanol, and acetonitrile, ${ }^{46,47}$ while quinidine is very soluble in chloroform solvents, moderately soluble in alcohol and benzene, and slightly soluble in water solvents. ${ }^{48}$ Another toxin, such as cyclosporine had been reported to be produced by $F$. solani f. sp. radicicola in modified liquid culture medium at $25^{\circ} \mathrm{C}$ for 7 days..$^{49} \mathrm{~F}$. solani M11 produces T-2 toxin, trichothecene, and solaniol in Czapek dox peptone medium at $25^{\circ} \mathrm{C}$ for 12 days. ${ }^{50} \mathrm{~A}$. sydowii produced sydonic acid in liquid medium with an initial $\mathrm{pH} 7.2$ at $28^{\circ} \mathrm{C}$ for 3 days, ${ }^{51}$ while Diaporthe produced phomopsin A in Czapek Dox broth at $24^{\circ} \mathrm{C}$ for 28 days. ${ }^{46}$ Regardless of toxin solubility, as these fungi may produce an unwanted substance, consideration should be taken when in vitro production of quinidine using these fungi is brought into practice.

Quinidine is a high-value substance. In this study, quinidine production by F. solani, F. oxysporum, and A. sydowii was higher than that of Diaporthe sp. and D. lithicola. Further, the amount of quinidine produced by Diaporthe sp. $(8.913 \mu \mathrm{g})$ and D. lithicola (11.148 $\mu \mathrm{g}$ ) in $200 \mathrm{~mL}$ PDB medium after 21 days of incubation was much higher than by $D$. phaseolorum (3-5 $\mu \mathrm{g} / \mathrm{L})$ and Schizophyllum sp. (0.01 $\mu \mathrm{g} / \mathrm{L})$ on synthetic medium $\mathrm{pH} 6.2$ after 4 days of incubation. ${ }^{18,19}$ This indicates that all the fungi studied are prospective agents for quinidine production.

The quinidine production from five $C$. calisaya endophytic fungi was still lower than that from $C$. calisaya bark extraction (2.240 $\mu \mathrm{g} / \mathrm{g}){ }^{52}$ However, compared with quinidine production in $C$. ledgeriana cell culture $(349.38 \mu \mathrm{g} / \mathrm{g})$, in vitro quinidine production from $A$. sydowii and $F$. solani was higher. In contrast, quinidine production from these fungi was lower than in the cell culture ( $8.078 \mu \mathrm{g} / \mathrm{g}$ ) modified by adding $5 \mathrm{ppm}$ of paclobutrazol and incubating it under $10 \mu \mathrm{mol} / \mathrm{m}^{2} / \mathrm{sec}$ light intensity. ${ }^{14}$ Nonetheless, quinidine production from endophytic fungi is more beneficial than that from plants, considering that its production requires a shorter time. An attempt to scale up quinidine production should, therefore, be pursued using $F$. solani, which is capable of producing the highest amount of quinidine with low biomass production using $\mathrm{PDB}$ medium with an initial $\mathrm{pH}$ of 6.2 and incubation under light. 


\section{CONCLUSION}

In quinidine production by $A$. sydowii, Diaporthe sp., $D$. lithicola, $F$. oxysporum, and $F$. solani, fungal endophytes from $C$. calisaya, was affected by light and the initial pH of the medium. Quinidine production by $A$. sydowii, F. oxysporum, and $F$. solani were higher with incubation under continuous light and an initial medium $\mathrm{pH}$ of 6.2 , while Diaporthe $\mathrm{sp}$. and $D$. lithicola were higher with incubation under continuous darkness and an initial medium $\mathrm{pH}$ of 6.8. In vitro culture of $F$. solani in PDB medium with an initial $\mathrm{pH} 6.2$ and with incubation under continuous light produced the highest concentration of quinidine with low biomass and thus could potentially be used for quinidine production. Five endophytic fungi from $C$. calisaya, mainly $F$. solani, are natural resources that could be exploited commercially for quinidine production. Production under optimum light and initial medium $\mathrm{pH}$ were considered as economically and environmentally friendly conditions. However, the stability of this quinidine production under optimum conditions should be further investigated to find models for production on an industrial scale.

\section{ACKNOWLEDGMENTS}

The authors would like to thank IPBCC for providing the fungal cultures.

Conflicts of interest: No conflict of interest was declared by the authors. The authors alone are responsible for the content and writing of the paper.

\section{REFERENCES}

1. Pengelly A. Medicinal Plant: An Introduction to The Chemistry and Therapeutics of Herbal Medicine. $2^{\text {nd }}$ ed. Crows Nest (AU); Allen \& Unwin; 2004:133-140.

2. [WHO] World Health Organization. World Malaria Report, 2016. Available from: http://www.who.int/malaria/publica-tions/world-malariareport-2016/report/en/

3. Kushwah P, Das P, Badore NS, Salvekar V, Deshmukh N. Evaluation of antimicrobial activity of Cinchona calisaya bark on Staphylococcus by agar well diffusion method. Pharm Biol Eval. 2016;3:272-274.

4. Krishnaveni M, Suresh K. Induction of apoptosis by quinine in human laryngeal carcinoma cell line. Int J Curr Res Aca Rev. 2015;3:169-178.

5. Noriega P, Sola M, Barukcic A, Garcia K, Osorio E. Cosmetic antioxidant potential of extracts from species of the Cinchona pubescens (Vahl). Int J Phytocos Nat Ingred. 2015;2:14.

6. Nair KPP. The agronomy and economy of important tree crops of the developing world. Burlington (US); Elsevier; 2010:112.

7. Kacprzak K. Chemistry and biology of cinchona alkaloid. In Ramawat KG, Merillon JM, (eds). Natural Product. Heidelberg; Springer; 2013:605-641.

8. Kumar S, Guha M, Choubey V, Maity P, Bandyopadhyay U. Antimalarial drugs inhibiting hemozoin ( $\beta$ hematin) formation: A mechanistic update. Life Sci. 2007;80:813-828.

9. Kharal SA, Hussain Q, Ali S, Fakhuruddin. Quinine is bactericidal. J Pakistan Med Assoc. 2009;59:208-212.

10. Wang S, Melkoumian Z, Woodfork KA, Cather C, Davidson AG, Wonderlin WF, Strobl JS. Evidence for an early G1 lonic Event Necessary for cell cycle progression and survival in the MCF-7 human breast carcinoma cell line. J Celll Physiol. 1998;176:456-464.

11. Kowey PR. Pharmacological effects of antiarrhytmic drugs. Arch Intercn Med. 1998;158:325-332.

12. (FDA) Food Drug and Administration. Quinidine gluconate extendedrelease tablets USP, 2010. Available from: https://www.fda.gov/Food/

13. Mathius NT, Lukman, Purwito A. In vitro micrografting technique of Cinchona succirubra with Cinchona ledgeriana. J Menara Perkebunan. 2006;74:63-75.

14. Ratnadewi D, Sumaryono. Quinoline alkaloids in suspension cultures of Cinchona ledgeriana treated with various substances. Hayati J Biosci. 2010;17:179-182.

15. Strobel G, Daisy B, Castillo U, Harper J. Natural products from endophytic microorganisms. J Nat Prod. 2004;67:257-268.

16. Simanjuntak P, Parwati T, Bustanussalam, Prana TK, Shibuya $H$. Produksi alkaloid kuinina oleh beberapa mikroba endofit dengan penambahan zat induser (studi mikroba endofit tanaman Cinchona sp.). Indonesian J Pharm. 2002;13:1-6.

17. Shibuya H, Kitamura C, Maehara S, Nagahata M, Winarno H, Simanjutak P, Kim HS, Wataya Y, Ohashi K. Transformations of Cinchona alkaloids into 1-N-oxides derivatives by endophytic Xylaria sp. isolated from Cinchona pubescens. Chem Pharm Bull. 2003;51:71-74.

18. Maehara S, Simanjuntak P, Maetani Y, Kitamura C, Ohashi K, Shibuya H. Bioproduction of cinchona alkaloids by the endophytic fungus Diaporthe $\mathrm{sp}$. associated wit Cinchona ledgeriana. Chem Pharm Bull. 2012;60:1301-1304.

19. Maehara S, Simanjuntak P, Maetani Y, Kitamura C, Ohashi K, Shibuya $\mathrm{H}$. Ability of endophytic filamentous fungi associated with Cinchona ledgeriana to produce cinchona alkaloids. J Nat Med. 2013;67:421-423.

20. Maehara S, Agusta A, Kitamura C, Ohashi K, Shibuya H. 2015. Composition of the endophytic filamentous fungi associated with Cinchona ledgeriana seeds and production of Cinchona alkaloids. J Nat Med. 2015;70:271-275.

21. Radiastuti N, Rahayu G, Okane I, Hidayat I, Achmadi SS. Alkaloid profile of endophytic Diaporthe sp. from Cinchona calisaya. J Penelitian Teh dan Kina. 2015;18:87-99.

22. Gogoi DK, Hari P, Boruah D, Saikia R, Bora TC. Optimization of process parameters for improved production of bioactive metabolite by a novel endophytic fungus sp. DF2 isolated from Taxus wallichiana of North East India. World J Microbiol Biotechnol. 2008;24:79-87.

23. Mathan S, Subramanian V, Nagamony S. Optimization and antimicrobial metabolite production from endophytic fungi Aspergillus terreus KC 582297. Eur J Exp Biol. 2014;3:138-144.

24. Norman SM, Maier VP, Echols LC. Influence of nitrogen source, thiamine, and light on biosynthesis of abscisic acid by Cercospora rosicola Passerini. Appl Environ Microbiol. 1981;4:981-985.

25. Tisch D, Schmoll M. Light regulation of metabolic pathways in fungi (review). Appl Microbiol Biotechnol. 2010;85:1259-1277.

26. Soliman SSM, Raizada MN. Darknes: a crucial factor in fungal taxol production. Front Micobiol. 2018;9:1-7.

27. Hidayat I, Radiastuti N, Rahayu G, Achmadi SS, Okane I. Three quinine and cinchonidine producing Fusarium species from Indonesia. Curr Res Environ Appl Mycol. 2016;6:20-34.

28. Fowler J, Cohen L, Jarvis P. Practical statistics for field biology. Chichester: John Wiley \& Sons Ltd; 1998:132. 
29. Aniszewski T. Alkaloid- secrets of life. Netherlands; Elsevier; 2007:83.

30. Dewick PM. Medicinal natural products a biosynthetic approach. $3^{\text {rd }}$ ed. United Kingdom; John Wiley \& Sons Ltd; 2009:380-383.

31. Tamerler C, Ullah M, Adlard MW, Keshavarz T. Effect of $\mathrm{pH}$ on physiology of Metarhizium anisopliae for production of swainsonine. FEMS Microbiol Lett. 1998;168:17-23.

32. Deacon, JW. Fungal Biology $\left(4^{\text {th }}\right.$ ed). Victoria; Blackwell Scientific;2006:147.

33. Denison $\mathrm{SH}$. pH regulation of gene expression in fungi. Fungal Genet Biol. 2000;29:61-71.

34. Graafmans WDJ. Metabolism in Penicillium isariiforme on exposure to light, with special reference to citric acid synthesis. J Gen Microbiol. 1974;82:247-252.

35. Aziz Nh, Moussa LAE. Influence of white light, near UV-irradiation and other environmental conditions on production of aflatoxin $B_{1}$ by Aspergillus flavus and ochratoxin A by Aspergillus ochraceus. Nahrung. 1997:41:150-154.

36. Velmurugan $\mathrm{P}$, Lee $\mathrm{YH}$, Vennil CK, Lakshmanaperumalsamy $\mathrm{P}$, Chae JC, Taek Oh B. Effect of light on growth, intracellular and extracellular pigment production by five pigment-producing filamentous fungi in synthetic medium. J Biosci Bioeng. 2010;109:346-350.

37. Wang L, Dai Y, Chen W, Shao Y, Chen F. Effects of light intensity and color on the biomass, extracellular red pigment and citrinin production of Monascus ruber. J Agric Food Chem. 2016;64:9506-9514.

38. Kim H, Son H, Lee Y. Effect of light on secondary metabolism and fungal development of Fusarium graminearum. J Appl Microbiol. 2013;116:380389.

39. Haggblom $\mathrm{P}$, Unestam T. Blue light inhibits mycotoxin production and increases total lipids and pigmentation in Alternaria alternate. Appl Environ Microbiol. 1979;38:1074-1077.

40. Cerda-Olmedo E. Phycomyces and the biology of light and color. FEMS Microbiol Rev. 2001;25:503-512.

41. Avalos J, Schrott EL. Photoinduction of carotenoid biosynthesis in Gibberella fujikuroi. FEMS Microbiol Lett. 1990;66:295-298.
42. Hill EP. Effect of light on growth and sporulation of Aspergillus ornatus. J Gen Microbiol. 1976;95:39-44.

43. Keller NP, Knox BP. Keys players in the regulation of fungal secondary metabolism. In: Zeilinger S, Martin JF, Garcia-Estrada C, eds. Fungal Biology. Heidelberg: Springer;2015:13-22.

44. Parmar P, Oza VP, Subramanian RB. Optimization of fusaric acid production by Fusarium oxysporum f.sp. lycopersici using responses surface methodology. Indian J Sci Technol. 2010;3:411-416.

45. Proctor RH, Busman M, Ah Seo J, Lee YW, Plattner RD. A fumonisin biosynthetic gene cluster in Fusarium oxysporum strain 0-1890 and the genetic basis for B versus C fumonisin production. Fungal Genet Biol. 2008;45:1016-1026.

46. Schloß S, Weedell I, Koch M, Rohn S, Maul R. Biosynthesis and characterization of 15N6-labeled phomopsin A, a lupin associated mycotoxin produced by Diaporthe toxica. Food Chem. 2015;177:61-65.

47. Gelderblom WCA, Jaskiewicz K, Marasas WFO, Thiel PG, Horak RM, Vleggaar R, Kriek NPJ. Fumonisins- novel mycotoxins with cancer promoting activity produced by Fusarium moniliforme. Appl Environ Microbiol.1998;54:1806-1811.

48. Weast RC. Handbook of chemistry and physics. $52^{\text {nd }}$ ed. lowa: CRC Pr; 1971:242-475.

49. Honraet K, De Vos MM, Summerbell RC, van Kempen I, De Saeger $\mathrm{S}$, Vermeersch H, van Peteghem C, Nelis HJ. Recurrent colonization of successively implanted tracheoesophageal vocal prostheses by a member of the Fusarium solani species complex. J Clin Microbiol. 2005:43:770-777.

50. Ishii K, Sakai K, Ueno Y, Tsunoda H, Enomoto M. Solaniol a toxic metabolite of Fusarium solani. Appl Microbiol. 1971;22:718-720.

51. Xu X, Zhao S, Yin L, Yu Y, Chen Z, Shen H, Zhou L. A new sydonic acid derivative from a marine derived-fungus Aspergillus sydowii. Chem Nat Compd. 2017;53:1056-1058.

52. Maldonado C, Barnes CJ, Cornet C, Holmfred E, Hansen SH, Persson C, Antonelli A, Ronsted N. Phylogeny predicts the quantity of antimlarial alkaloids within the iconic yellow Cinchona bark (Rubiaceae: Cinchona calisaya). Front Plant Sci. 2017;8:1-16. 